\title{
Effect of Training System, Rootstock, and Cultivar on Sweet Cherry Powdery Mildew Foliar Infections
}

\author{
Jill Marie Calabro ${ }^{1,2}$ and Robert A. Spotts \\ Oregon State University, Mid-Columbia Agricultural Research and \\ Extension Center, 3005 Experiment Station Drive, Hood River, OR 97031
}

\author{
Gary G. Grove \\ Washington State University, Irrigated Agricultural Research and Extension \\ Center, Prosser, WA 99350
}

Additional index words. sweet cherry powdery mildew, Podosphaera clandestina, sweet cherry

\begin{abstract}
Selected orchard practices were evaluated for their influence on powdery mildew infections (caused by Podosphaera clandestina) of sweet cherry in two orchards in Oregon. Three training systems (Spanish bush, steep leader, and central leader), four rootstocks (Edabriz, Maxma 14, Mazzard, Pontaleb), and five cultivars (cvs. Bing, Lapins, Regina, Staccato, and Sweetheart) were included in our studies. Mildew severity was significantly the highest on trees trained on the Spanish bush system $(10.7 \%$ and $16.6 \%$ of leaf surface colonized in 2003 and 2004, respectively) when compared with Vogel central leader $(2.7 \%$ and $10.8 \%$ of leaf surface colonized in 2003 and 2004 , respectively) and steep leader (5.3\% and $6.9 \%$ of leaf surface colonized in 2003 and 2004 , respectively) systems. Foliar mildew infections were significantly the lowest on rootstock Edabriz (0.5\% and 1.5\% of leaf surface colonized in 2003 and 2004, respectively). A range of susceptibilities was noted among the cultivars tested. Cv. Regina had the lowest level of foliar mildew infections in both 2003 and $2004(0.1 \%$ and $0 \%$ of leaf surface colonized, respectively), whereas cvs. Staccato and Sweetheart had the highest $(32.6 \%$ and $33.4 \%$ of leaf surface colonized, respectively). Results indicate that selection of training system, rootstock, and cultivar may impact the severity of powdery mildew infestations in sweet cherry orchards.
\end{abstract}

As production of sweet cherries (Prunus avium L.) has flourished in Oregon and Washington, so has powdery mildew caused by the fungus Podosphaera clandestina (Wall.:Fr) Lev. Fruit infected with P. clandestina develop unsightly blemishes after harvest, rendering them less desirable for consumers. Increased incidence and severity of powdery mildew may be related to changes in sweet cherry production such as the implementation of high-density plantings, the use of late-season maturing cultivars, climatic changes, and changes in pruning strategies to emphasize a more pedestrian orchard, where the majority of the orchard can be harvested from the ground.

Growers are heavily reliant on fungicides to manage powdery mildew. Planting mildewresistant cultivars and implementing pruning techniques that encourage open canopies are

\footnotetext{
Received for publication 26 Sept. 2008. Accepted for publication $11 \mathrm{Dec}$. 2008.

We thank the Oregon Sweet Cherry Commission and the Washington Tree Fruit Research Commission for partial funding of the research.

Use of trade names in this article does not imply endorsement by Oregon State University of the products named or criticism of similar products not mentioned.

${ }^{1}$ Former graduate student.

${ }^{2}$ To whom reprint requests should be addressed; e-mail jill.calabro@valent.com.
}

two examples of alternative strategies used by growers. To date, there have been no studies on the effects of canopy management on cherry powdery mildew infestation levels.

Rootstocks directly control scion vigor, which may indirectly impact the development of $P$. clandestina. Sweet cherry rootstocks are generally selected based on their promotion of a dwarfing habit and fruiting precocity. Cherry cultivars are known to vary in their mildew susceptibility (Olmstead et al., 2000). For example, cv. Bing is considered highly susceptible, and 'Lapins' is considered moderately to slightly susceptible.

Studies were undertaken to examine the effects of selected horticultural practices on the infection of sweet cherry by $P$. clandestina on sweet cherry. We evaluated mildew severity as a response to three training systems, four rootstocks, and five cultivars.

\section{Materials and Methods}

Two orchards (Hazel Dell and the Cemetery Block), located in The Dalles, OR, were selected for the study. The Hazel Dell orchard was established in 1997 as part of a study to evaluate three training systems and several rootstock selections on production of sweet cherry cultivar Bing. The training systems were Vogel central leader, Spanish bush, and steep leader. Clusters of trees with the same rootstock and training system were randomly distributed throughout the orchard. Because the orchard was established in 1997, many trees died and were replaced with sweet cherry trees of varying cultivar and rootstock. We selected four rootstocks in this study, Edabriz, Maxma (MxM) 14, Mazzard, and Pontaleb, based on current grower interest and tree availability. At least five and no more than 10 trees of each training system and rootstock combination were randomly selected for leaf collections.

The Cemetery Block orchard was established in 1996 and 1997 to evaluate the performance of several different cultivars. All cultivars were grafted on Mazzard rootstock and trained using the steel leader system, two industry standards at the time the Cemetery Block was planted. Over 20 cultivars had been planted in this orchard, all in groups of 10 to 15 trees in a row. We selected five cultivars, Bing, Lapins, Regina, Staccato, and Sweetheart, for evaluation based on grower interest and tree availability. At least five and no more than 10 trees from each cultivar were randomly selected from the Cemetery Block.

In Aug. 2003 and Aug. 2004, leaves were collected from both orchards and visually rated for disease severity defined as the percent of the leaf surface colonized by $P$. clandestina. Ten shoots of the current year's growth were collected per tree, and the terminal 10 leaves of each branch were each evaluated.

Data from the two orchards were not combined in the statistical analyses because a test of homogeneity determined the 2 years were independent of each other. All data were subjected to analysis of variance using S-Plus (Insightful Corporation, Seattle, WA) statistical analysis software. Where treatment effects were significant, treatment means were separated by the Tukey-Kramer method at a probability level of $P \leq 0.05$.

\section{Results and Discussion}

During both years of the study, mildew severity was greater in trees trained according to the Spanish bush system than trees trained to a Vogel central or steep leader system (Table 1). Spanish bush promotes heavy branching and dense foliage that diminishes air movement, spray penetration, and light penetration within the canopy. Shade, reduced temperature, ultraviolet radiation, and high relative humidity (Jarvis et al., 2002) are ideal conditions for powdery mildew development. In contrast to the Spanish bush system, the Vogel central and steep leader systems promote moderate growth characteristics that encourage greater air flow, light penetration, and spray penetration within the canopy (Long, 2003), conditions much less conducive to the development of powdery mildew than the microclimate of the Spanish bush system.

Rootstock influenced the severity of mildew infections on the scion. In both years, mildew severity was highest on Mazzard and lowest on Edabriz (Table 1). This difference is likely related to air movement within the 
Table 1. Effects of training system, rootstock, and cultivar on severity of powdery mildew (caused by Podosphaera clandestina) on foliage of sweet cherry trees (Prunus avium). ${ }^{\mathrm{z}}$

\begin{tabular}{clrr}
\hline & & \multicolumn{2}{c}{ Year } \\
\cline { 2 - 4 } & & 2003 & 2004 \\
\hline Training & Vogel Central & $2.7 \mathrm{~b}$ & $10.8 \mathrm{~b}$ \\
system $^{\mathrm{y}, \mathrm{x}, \mathrm{w}}$ & $\quad$ Leader & & \\
& Spanish Bush & $10.7 \mathrm{a}$ & $16.6 \mathrm{a}$ \\
& Steep Leader & $5.3 \mathrm{~b}$ & $6.9 \mathrm{~b}$ \\
Rootstock $^{\mathrm{y}, \mathrm{x}, \mathrm{w}}$ & Edabriz & $0.5 \mathrm{~b}$ & $1.5 \mathrm{c}$ \\
& Maxma & $7.9 \mathrm{a}$ & $17.9 \mathrm{a}$ \\
& (MxM) 14 & & \\
& Mazzard & $8.8 \mathrm{a}$ & $15.7 \mathrm{ab}$ \\
& Pontaleb & $8.5 \mathrm{a}$ & $11.0 \mathrm{~b}$ \\
& 2845 & & \\
& Bing & $7.4 \mathrm{~cd}$ & $7.2 \mathrm{c}$ \\
& Lapins & $11.2 \mathrm{bc}$ & $17.7 \mathrm{~b}$ \\
& Regina & $0.1 \mathrm{~d}$ & $0 \mathrm{c}$ \\
& Staccato & $20.4 \mathrm{~b}$ & $32.6 \mathrm{a}$ \\
& Sweetheart & $33.4 \mathrm{a}$ & $20.4 \mathrm{~b}$ \\
\hline
\end{tabular}

${ }^{\mathrm{z}}$ Samples were collected from two separate orchards in The Dalles, OR, on Aug. 2003 and Aug. 2004.

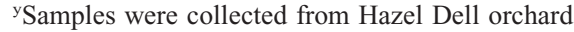
in The Dalles, OR.

${ }^{\mathrm{x}}$ Cultivar Bing.

${ }^{w}$ Average percent of leaf surface colonized by $P$. clandestina. Numbers followed by the same letter within columns and categories are not significantly different at $P \leq 0.05$. Means were separated with the Tukey-Kramer method.

vSamples were collected from The Cemetery Block in The Dalles, OR.

uTrees were trained on a steep leader system, and scions were grafted on Mazzard rootstock. canopy, because trees grafted onto Mazzard have a much larger and denser canopy. This research showed that vigor of Pontaleb, Maxma 14, and Mazzard was similar, but vigor of Edazbiz was approximately half that of the other three rootstocks. It is advisable that trees grafted onto Gisela and other new rootstocks be evaluated for mildew severity because 'Bing' on Mazzard was shown to be $26 \%$ and $51 \%$ more vigorous than 'Bing' on Gisela 6 or Gisela 5, respectively, based on trunk cross-sectional area (Whiting et al., 2005).

A range of powdery mildew resistance levels was evident among the five cultivars studied. Cultivar Regina had the lowest severity of foliar mildew during both years of the study (Table 1). Relative to the four other cultivars in our studies, cv. Bing was very resistant to $P$. clandestina infection. This is in contrast to previous work, in which cv. Bing was rated as highly susceptible, although we used a different rating system than that used by Olmstead et al. (2000). We found cv. Lapins to be moderately susceptible because disease development was reduced on cv. Bing and Regina and higher on cvs. Staccato and Sweetheart (Table 1). This concurs with conclusions of previous studies in which 'Lapins' was found to be moderately to slightly susceptible (Olmstead et al., 2000). The latest maturing cultivars, Sweetheart and Staccato, had the highest severity of mildew in 2003 and 2004, respec- tively (Table 1). Late-maturing cultivars historically have a higher $P$. clandestina infection levels for unknown reasons.

Our results illustrate the importance of considering powdery mildew when selecting training systems, rootstocks, and cultivars for new orchards. If the orchard has the potential for high $P$. clandestina infection levels, then training system, rootstock, and/or cultivar should be carefully chosen. Selecting a cultivar such as Regina and/or using a Vogel central leader training system can likely lower the severity or slow the development of a powdery mildew epidemic and ultimately reduce dependence on fungicides.

\section{Literature Cited}

Jarvis, W.R., W.D. Gubler, and G.G. Grove. 2002. Epidemiology of powdery mildews in agricultural pathosystems, p. 169-199. In: R.R., Belanger, W.R. Bushnell, A.J. Dik, and R.L. Carter (eds.). The powdery mildews, a comprehensive treatise. APS Press, St. Paul, MN.

Long, L.E. 2003. Cherry training systems: Selection and development. Corvallis, OR. Oreg. State Univ. Ext. Serv. Publication PNW543.

Olmstead, J.W., G.A. Lang, and G.G. Grove. 2000 A leaf disk assay for screening sweet cherry genotypes for susceptibility to powdery mildew. HortScience 35:274-277.

Whiting, M.D., G. Lang, and D. Ophardt. 2005. Rootstock and training system affect sweet cherry growth, yield, and fruit quality. HortScience 40:582-586. 